\title{
Endophytic bacteria from banana cultivars and their antifungal activity
}

\author{
A. Souza ${ }^{1}$, J.C. Cruz $^{2}$, N.R. Sousa ${ }^{2}$, A.R.L. Procópio ${ }^{1}$ and G.F. Silva ${ }^{2}$ \\ ${ }^{1}$ Laboratório de Biotecnologia e Recursos Naturais, \\ Universidade do Estado do Amazonas, Manaus, AM, Brasil \\ ${ }^{2}$ Laboratório de Biologia Molecular, Embrapa Amazônia Ocidental, \\ Manaus, AM, Brasil \\ Corresponding author: G.F. Silva \\ E-mail: gilvan.silva@embrapa.br
}

Genet. Mol. Res. 13 (4): 8661-8670 (2014)

Received July 10, 2013

Accepted December 2, 2013

Published October 27, 2014

DOI http://dx.doi.org/10.4238/2014.October.27.6

\begin{abstract}
Endophytic microorganisms consist of fungi, bacteria, and actinomycetes that play important roles in the process of plant adaptation to the environment. Currently, the natural associations between microorganisms and plant species are being explored for a large number of biotechnological applications. In this study, 122 endophytic bacteria were isolated from 5 cultivars of Musa spp from the state of Amazonas (Brazil). Four strains were selected because they exhibited antagonistic activities against Fusarium oxysporum f. sp cubense and Colletotrichum guaranicola, with inhibitions ranging from 19 to $30 \%$ and 27 to $35 \%$, respectively. Phylogenetic analysis of the $16 \mathrm{~S}$ rDNA regions of these bacteria with antifungal activity showed that they are phylogenetically related to 3 different species of Bacillus - B. amyloliquefaciens, B. subtilis subsp subtilis, and B. thuringiensis.
\end{abstract}

Key words: Bacillus; Fusarium oxysporum f. sp cubense; Endophytic; Biological control; Musa spp 


\section{INTRODUCTION}

Endophytes are present in plant tissues and do not cause damage to the plant or produce external structures that emerge from the plant tissues (Azevedo and Araujo, 2007). In general, endophytes are fungi and bacteria that play important roles in the environmental adaptation process of plants (Mendes and Azevedo, 2007).

Plants are considered complex microecosystems in which different niches can be exploited by an extensive variety of microorganisms, including endophytes (Azevedo et al., 2000). Studies of plant/microorganism interactions and the role of these microorganisms in plants have indicated their utility for a large number of applications, such as the biological control of numerous diseases (Zheng et al., 2011; Ceballos et al., 2012), promotion of plant growth (Hallmann et al., 1997; Coombs et al., 2004; Montañez et al., 2012), and bioremediation of contaminated environments (Ma et al., 2011).

Endophytes have been isolated from different parts of plants, such as roots, stems, nodes, leaves, and fruits, and from a wide variety of plants, including many that are of agricultural interest such as grapevines (Bell et al., 1995), cotton (Quadt-Hallmann et al., 1997), rice (Stolzfus et al., 1997), tomatoes (Pillay and Nowak, 1997), maize (Araújo et al., 2000), wheat and sorghum (Zinniel et al., 2002), potatoes (Reiter et al., 2003), banana plants (Weber et al., 2007), and sugar cane (Lira-Cadete et al., 2012).

In banana plants, an analysis of the response of endophytic bacterial communities in plantlets derived from tissue cultures infected with a Fusarium oxysporum f. sp cubense (FOC) race 4 pathogen showed that antagonist endophytic bacterial communities tended to increase in $F O C$-inoculated banana plants, indicating that the presence of the pathogen played a role in the selection of antagonists (Lian et al., 2008). Endophytic bacteria isolated from older banana leaves exhibited higher percentages of antagonistic activity against Mycosphaerella fijiensis, which affected the morphology of the mycelia and ascospores (Ceballos et al., 2012).

Currently, natural associations between microorganisms and plant species are being explored for their potential use in a large number of biotechnological applications such as drug discovery. Strobel et al. (2004) noted that endophytic actinomycetes that were associated with medicinal plants, especially in the tropics, could be a rich source of functional metabolites. Endophytes have proven to be rich sources of new natural compounds possessing broad spectra of biological activities and high levels of structural diversity (Pimentel et al., 2011). Thus, the aim of this study was to isolate and select endophytic bacteria with antifungal activity from cultivars of Musa spp that were grown in the State of Amazonas, Brazil.

\section{MATERIAL AND METHODS}

\section{Plant sources}

Endophytic bacteria were isolated from 5 cultivars of banana - BRS Conquista (genotype BB), Pinsangue Seilão (AAA), FHIA 18 (AAAB), and Pacovan (AAB) - for which samples were obtained from the experimental area of Empresa Brasileira de Pesquisa Agropecuária (EMBRAPA Amazônia Ocidental) Manaus, AM, and cultivar Maçã (AAB), which was collected at a crop in Manacapuru, Amazonas. 


\section{Bacterial isolation}

Leaf tissue samples for each cultivar were collected at random from healthy adult plants, stored at room temperature, and processed within $24 \mathrm{~h}$ after collection. Initially, samples were washed in water, cut into pieces, and subjected to sterilization procedures with $70 \%$ ethanol, followed by disinfection with a solution of $3 \%$ sodium hypochlorite for 1 min, another wash with $70 \%$ ethanol, and 2 washes in sterile distilled water.

Endophytic bacteria were isolated from 20 fragments of 4 to $5 \mathrm{~mm}$, inoculated in tryptic soy broth, and incubated for up to 2 days at $28^{\circ} \mathrm{C}$. The bacterial colonies were isolated from leaf fragments and then deposited in the Amazon Biotechnology Center (CBA) collection.

\section{Antagonistic activity tests}

In vitro antagonistic activity tests were performed against FOC and Colletotrichum guaranicola, which are pathogens of banana and guarana (Paullinia cupana var. sorbilis) plants, respectively. Endophytic bacteria were evaluated by the paired culture technique. Mycelial discs of $5 \mathrm{~mm}$ that were obtained from each fungus were placed on Petri dishes containing enriched potato dextrose agar medium $(200 \mathrm{~g} / \mathrm{L}$ potato, $20 \mathrm{~g} / \mathrm{L}$ dextrose, and $15 \mathrm{~g} / \mathrm{L}$ agar $)$ and incubated at $28^{\circ} \mathrm{C}$ for 3 days. Bacteria were inoculated, and incubation continued at $28^{\circ} \mathrm{C}$ for a further 6 days for $F O C$ and 8 days for $C$. guaranicola. After this period, the average diameters of the pathogens and antagonistic colonies were determined using a caliper.

\section{DNA extraction}

Bacterial DNA was extracted according to a previously modified protocol by Sun et al. (2008). Quantitation was performed with a spectrophotometer (NanoDrop-Thermo) and $0.8 \%$ agarose gel.

\section{Molecular identification by $16 \mathrm{~S}$ rDNA sequencing}

16S rDNA from M10, M28, and PS6 isolates was amplified using primers 27F (5'-AGAGTTTGATCMTGGCTCAG-3') and 1492R (5'-GGTTACCTTGTTACGACTT-3'), while the primers V3F (5'-CCTACGGGAGGCAGCAG-3') and V3R (5'-ATTACCGCGGCTGCTGG-3') were used for the $\mathrm{M} 05$ isolate under the following polymerase chain reaction (PCR) conditions: $4 \mathrm{~min}$ at $94^{\circ} \mathrm{C} ; 30$ cycles of $30 \mathrm{~s}$ at $94^{\circ} \mathrm{C}, 1 \mathrm{~min}$ at $60^{\circ} \mathrm{C}$, and $1 \mathrm{~min}$ at $72^{\circ} \mathrm{C}$; and a final extension step of $10 \mathrm{~min}$ at $72^{\circ} \mathrm{C}$. Reactions were carried out with $10 \mathrm{X}$ buffer $(500 \mathrm{mM} \mathrm{KCl}, 100 \mathrm{mM}$ Tris-HCl, $\mathrm{pH} 8.4,1 \%$ Triton X-100), $2 \mathrm{mM} \mathrm{MgCl}, 0.2 \mathrm{mM}$ of each dNTP, 50 ng DNA, 0.5 $\mathrm{mM}$ of each primer, and $1 \mathrm{U}$ Taq polymerase (Phoneutria). The PCR products were purified with PEG8000 and sequenced using primers 27F, 1492R, V3F, and V3R.

\section{Data analysis}

Triplicate data from the antagonistic activity tests were subjected to analysis of variance and the Tukey test $(\mathrm{P}<0.01)$. The percentage of inhibition was calculated based on the ratio between the average inhibition and the average growth of the control. 
Phylogenetic analysis was performed by comparing 16S rDNA sequences from the isolates M05, M10, M28, and PS6 with different species deposited in the National Center for Biotechnology Information database (http://www.ncbi.nlm.nih.gov). The sequences were aligned with multiple sequence comparison by log-expectation, and the phylogenetic analysis based on the dataset alignment was performed with maximum likelihood (ML) by Tamura and Nei (1993) with the aid of MEGA5 (Tamura et al., 2011). The clade stability of the tree resulting from ML analysis was assessed by bootstrap analysis with 1000 replicates.

\section{RESULTS}

One hundred twenty-two endophytic bacteria were isolated. Twenty-nine samples were isolates from the Maçã cultivar, 23 were isolates of the Pacovan cultivar, 9 isolates were from the BRS Conquista cultivar, and 55 isolates were obtained from the FHIA 18 cultivar (Table 1). Of the 5 cultivars used for the isolation of endophytic bacteria, only the Pisangue Seilão and Maçã cultivars had bacteria with potential use for an in vitro biological control.

\begin{tabular}{|c|c|c|c|c|c|c|c|c|c|c|c|}
\hline Maçã & $\begin{array}{l}\text { Collection } \\
\text { No. }\end{array}$ & FHIA18 & $\begin{array}{l}\text { Collection } \\
\text { No. }\end{array}$ & FHIA18 & $\begin{array}{l}\text { Collection } \\
\text { No. }\end{array}$ & Pacovan & $\begin{array}{l}\text { Collection } \\
\text { No. }\end{array}$ & $\begin{array}{l}\text { BRS } \\
\text { Conquista }\end{array}$ & $\begin{array}{l}\text { Collection } \\
\text { No. }\end{array}$ & $\begin{array}{l}\text { Pisangue } \\
\text { Seilão }\end{array}$ & $\begin{array}{l}\text { Collection } \\
\text { No. }\end{array}$ \\
\hline M01 & CBA-1869 & FH6B & CBA-1716 & FH14A & CBA-1702 & P1 & CBA-1748 & BRS3 & CBA-1739 & PS6* & CBA-1731 \\
\hline M02 & CBA-1870 & FH7C & CBA-1722 & FH9B & CBA-1730 & P1A & CBA-1804 & BRS12 & CBA-1745 & PS9 & CBA-1732 \\
\hline M03 & CBA-1871 & FH14 & CBA-1701 & FH1A & CBA-1706 & $\mathrm{P} 2 \mathrm{~A} 1$ & CBA-1806 & BRS10 & CBA-1741 & PS11 & CBA-1734 \\
\hline M04 & CBA-1872 & FH5A1 & CBA-1711 & FH5A & CBA-1712 & P2B & CBA-1807 & BRS10A & CBA-1742 & PS6A & CBA-1737 \\
\hline M05* & CBA-1873 & FH12C & CBA-1691 & FH6C & CBA-1717 & P2B1 & CBA-1803 & BRS10C & CBA-1744 & PS11A & CBA-1735 \\
\hline M06 & CBA-1874 & FH11E1 & CBA-1688 & FH9 & CBA-1728 & P3A & CBA-1761 & BRS6 & CBA-1733 & PS6A1 & CBA-1738 \\
\hline M07 & CBA-1875 & FH9A1 & CBA-1693 & FH11C & CBA-1762 & P6 & CBA- 1750 & BRS12F & CBA-1747 & & \\
\hline M08 & CBA-1876 & FH14C & CBA-1705 & FH11D & CBA-1764 & P8 & CBA-1751 & BRS10B & CBA-1743 & & \\
\hline M09 & CBA-1877 & FH12B & CBA-1690 & FH10C & CBA-1685 & P11B & CBA-1758 & BRS12.1 & CBA-1746 & & \\
\hline M10* & CBA-1878 & FH10B1A & CBA-1683 & FH8 & CBA-1724 & P11E & CBA-1765 & & & & \\
\hline M11 & CBA-1879 & FH5 & CBA-1710 & FH12D & CBA-1694 & P13 & CBA-1769 & & & & \\
\hline M12 & CBA-1880 & FH11 & CBA-1686 & FH8B & CBA-1726 & P13D & CBA-1774 & & & & \\
\hline M13 & CBA-1881 & FH10B1 & CBA-1681 & FH6D & CBA-1719 & $\mathrm{P} 2 \mathrm{~A}$ & CBA-1805 & & & & \\
\hline M14 & CBA-1882 & $\mathrm{FH} 6 \mathrm{Cl} 1$ & CBA-1718 & FH11E & CBA-1668 & P14A & CBA-1775 & & & & \\
\hline M15 & CBA-1883 & FH11E1A & CBA-1689 & FH14A1 & CBA-1703 & P14B & CBA-1777 & & & & \\
\hline M16 & CBA-1884 & FH7B & CBA-1721 & FH1D & CBA-1709 & $\mathrm{P} 14 \mathrm{C}$ & CBA-1779 & & & & \\
\hline M17 & CBA-1885 & FH13 & CBA-1695 & FH7A & CBA-1720 & P14D1 & CBA-1781 & & & & \\
\hline M18 & CBA-1886 & FH10B & CBA-1680 & FH8A & CBA-1725 & P14E & CBA-1782 & & & & \\
\hline M19 & CBA-1887 & FH13A & CBA-1696 & FH13D1 & CBA-1700 & P15B & CBA-1784 & & & & \\
\hline M20 & CBA-1888 & FH10B1 & CBA-1681 & FH11 & CBA-1686 & $\mathrm{P} 15 \mathrm{C}$ & CBA-1786 & & & & \\
\hline M21 & CBA-1889 & FH13B & CBA-1697 & FH10 & CBA-1677 & P15D1 & CBA-1787 & & & & \\
\hline M22 & CBA-1890 & FH13D & CBA-1699 & FH5A1A & ACBA-1713 & P17E & CBA-1797 & & & & \\
\hline M23 & CBA-1891 & FH18C & CBA-1746 & FH16E & CBA-1749 & P18A & CBA-1798 & & & & \\
\hline M24 & CBA-1992 & FH11B & CBA-1727 & FH1B & CBA-1707 & & & & & & \\
\hline M25 & CBA-1993 & FH14B & CBA-1704 & FH1C & CBA-1708 & & & & & & \\
\hline M26 & CBA-1994 & FH9A & CBA-1729 & & & & & & & & \\
\hline M27 & CBA-1995 & FH7D & CBA-1723 & & & & & & & & \\
\hline M28* & CBA-1996 & FH9C & CBA-1682 & & & & & & & & \\
\hline M29 & CBA-1897 & FH10F & CBA-1714 & & & & & & & & \\
\hline
\end{tabular}

*Bacteria that exhibited antagonistic activity against Fusarium oxysporum f. sp cubense and Colletotrichum guaranicola.

Antagonistic activity against $F O C$ and $C$. guaranicola was detected in 4 isolates: 3 Maçã cultivar isolates (M05, M10, and M28) and 1 Pisangue cultivar isolate (PS6). The antagonistic activity data demonstrated differences in inhibition efficiency among isolates. Iso- 
late M28 showed the highest inhibition of C. guaranicola (35\%), followed by M05 (32\%), PS6 (30\%), and M10 (27\%). For FOC, isolate PS6 showed the highest inhibition rate (30\%), followed by M05 (28\%), M28 (24\%), and M10 (19\%) (Figures 1 and 2).

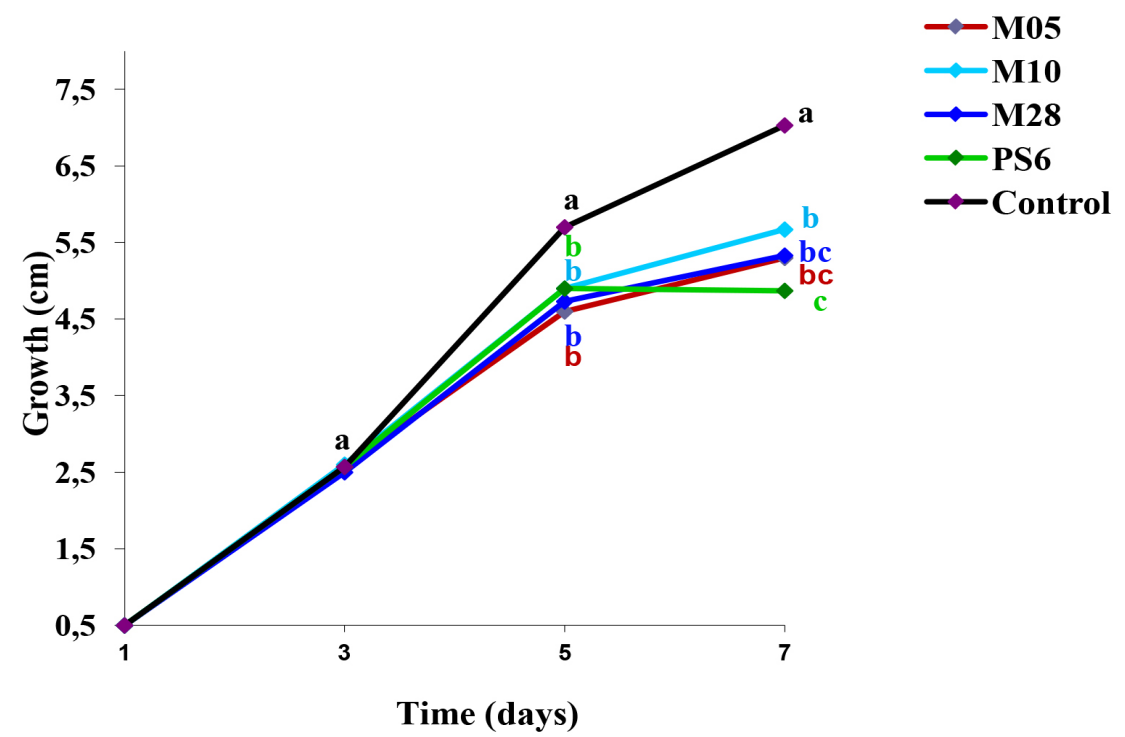

Figure 1. In vitro antagonistic activity test of endophytic bacteria against Fusarium oxysporum $\mathrm{f}$. sp cubense in a direct challenge. Averages followed by the same letter do not differ by the Tukey test $(\mathrm{P}<0.01 \%)$. M05, M10, and M28: isolates from the Maçã cultivar; PS6: isolate of the Pisangue Seilão cultivar.

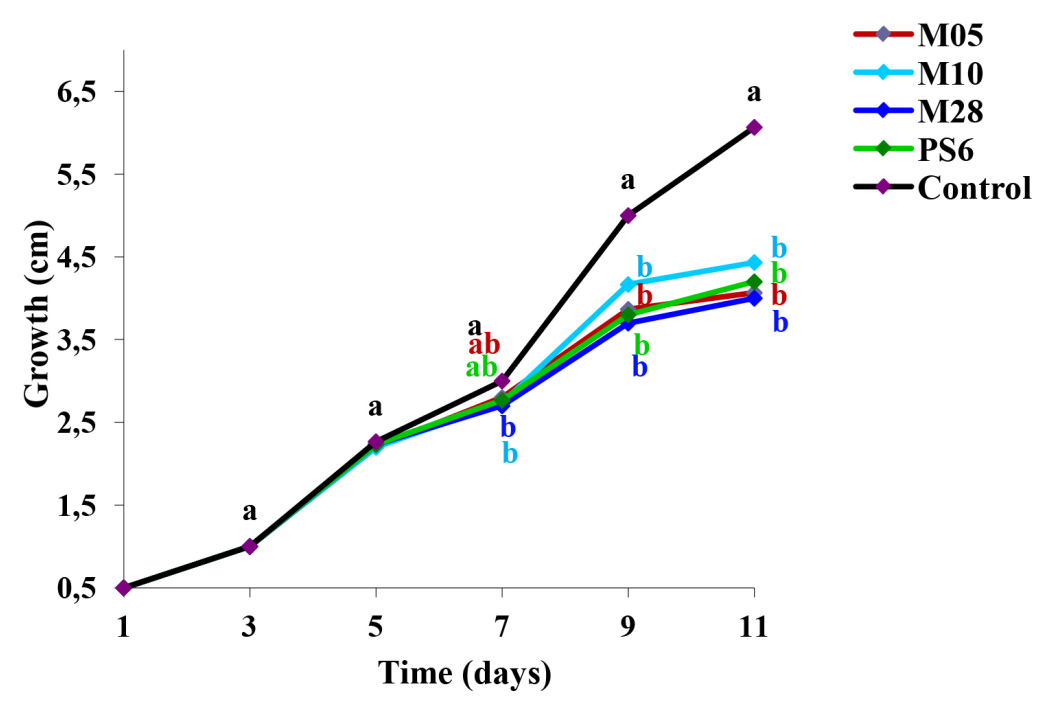

Figure 2. In vitro antagonistic activity test of endophytic bacteria against Colletotrichum guaranicola in a direct challenge. Averages followed by the same letter do not differ by the Tukey test $(\mathrm{P}<0.01 \%)$. M05, M10, and M28: isolates from the Maçã cultivar; PS6: isolate of the Pisangue Seilão cultivar. 
Phylogenetic analysis of the 16S rDNA of the 4 bacteria that exhibited antifungal activity revealed that these isolates corresponded to 3 different species of Bacillus. PS6 and M10 demonstrated higher correlation to B. amyloliquefaciens, M28 was most highly correlated to B. subtilis subsp subtilis (Figure 3), and the bacterium M05 was closely related to B. thuringiensis (Figure 4).

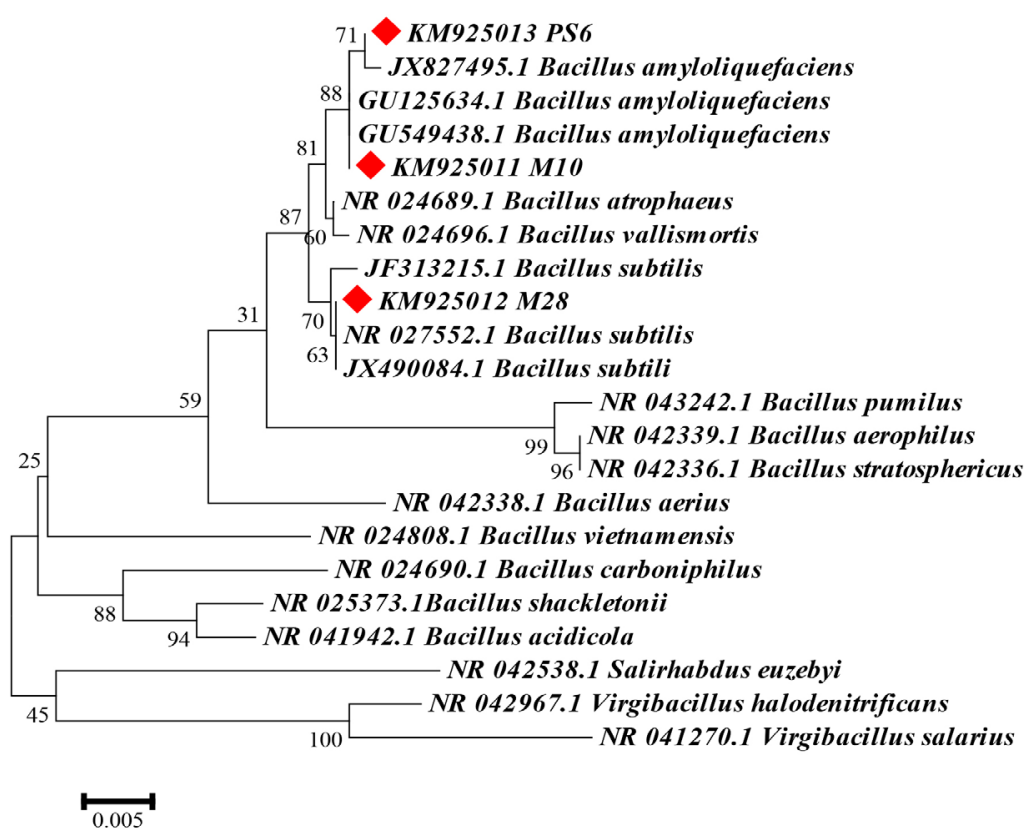

Figure 3. Phylogenetic relationships between endophytic bacteria based on partial 16S rDNA sequences by the maximum likelihood method described by Tamura and Nei (1993) performed using 1000 bootstrap replicates.

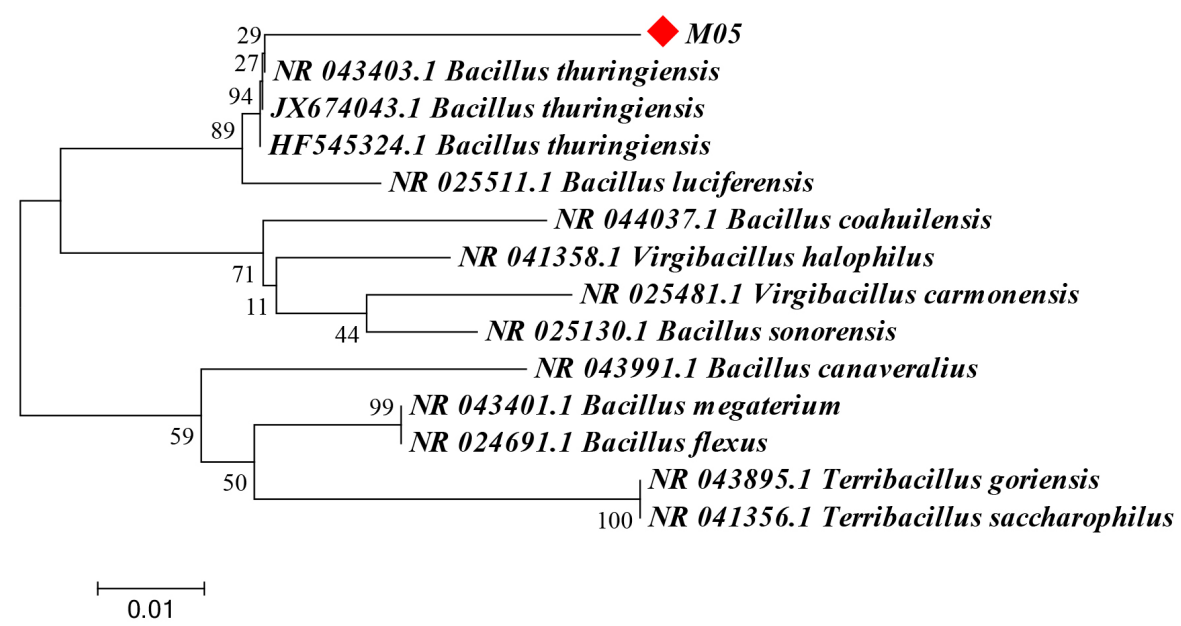

Figure 4. Phylogenetic relationships of endophytic bacteria based on partial 16S rDNA sequences by the maximum likelihood method described by Tamura and Nei (1993) performed using 1000 bootstrap replicates. 


\section{DISCUSSION}

The 4 endophytic bacteria with antifungal activity isolated in this study were obtained from 2 banana cultivars that were grown in fields without high disease pressure. The ratio of the number of isolates with antagonistic activity to the total number of isolated bacteria (4/122) was relatively lower than that found by Wang et al. (2012), who obtained 6 antagonistic bacteria of 57 bacterial strains that were isolated from the rhizospheres of healthy banana plants that were grown in a heavily wilted and diseased field. A greater number of endophytes with antagonistic activity have been observed in plants subjected to biotic stress (Lian et al., 2008).

In recent years, several endophytic bacteria with potential use in biological control or growth promotion were isolated from different banana cultivars. Weber et al. (2007) isolated bacterial endophytes from Musa spp, specifically from Pacovan and Prata cultivars in the state of Ceará (northeast of Brazil), and they identified bacteria with potential use in biocontrol and biofertilization. Thomas et al. (2008) identified the presence of culturable and non-culturable endophytes and analyzed the ubiquitous and intense association between endophytes and bananas, including their quiescent survival in apparently clean tissue cultures.

The 4 isolates with antagonistic activity against $F O C$ and $C$. guaranicola obtained in this study were characterized by sequencing the $16 \mathrm{~S}$ rDNA region. Results indicated that the isolates were phylogenetically related to 3 species of the genus Bacillus. Isolates PS6 and M10 grouped with B. amyloliquefaciens ( $88 \%$ bootstrap), while isolate M28 showed higher correlation to B. subtilis subsp subtilis (Figure 3).

Bacillus spp have been described as the most promising biological control agents, and several studies have demonstrated the potential of this genus for the control of pathogens in different plant cultures (Wulff et al., 2002; Kildea et al., 2008; Arguelles-Arias et al., 2009; Pérez-García et al., 2011).

Recently, B. amyloliquefaciens isolated from the rhizospheres of healthy banana plants in a field highly contaminated with $F O C$ exhibited an ability to promote the growth of banana plants and antagonistic activity against $F O C$ through the production of antifungal lipopeptides and volatile compounds (Wang et al., 2012). Research conducted by Yuan et al. (2012) also showed that B. amyloliquefaciens produced at least 11 volatile compounds capable of reducing mycelial growth and inhibiting the germination of $F O C$ pathogen spores. Some strains of $B$. amyloliquefaciens are also important plant growth-promoting rhizobacteria and can be used as bioorganic fertilizers to promote growth (Yuan et al., 2013). Isolated strains from activated sludge from a polluted river have also been evaluated for their potential in water remediation to remove nitrite-N and ammonia-N (Xie et al., 2013). Moreover, virucidal effects against herpes simplex virus 1 were detected with high concentrations of subtilosin, the cyclical antimicrobial peptide produced by B. amyloliquefaciens (Torres et al., 2013).

Isolate M28 (Table 1), which showed the highest inhibition rate against $C$. guaranicola, was identified as B. subtilis (Figure 3). Strains of $B$. subtilis have been used as biocontrol agents for diseases caused by fungi and bacteria (Zeriouh et al., 2011). B. subtilis also demonstrated in vitro activity against various species of Fusarium, and the component responsible for the antifungal activity was identified as fengycin, a lipopeptide commonly produced by $B$. subtilis (Rebib et al., 2012).

With the robust support of the bootstrap analysis, isolate M05 was determined to be phylogenetically closely related to B. thuringiensis (Figure 4). In most cases, B. thuringiensis 
has been associated with the biological control of insects, because it is capable of causing toxicity that is 24 times higher than that by an insecticide (Konecka et al., 2012); however, this species has also been shown to have activity against microorganisms. Mojica-Marín et al. (2008) revealed not only the antagonistic potential of $B$. thuringiensis against Rhizoctonia solani of the pepper plant but also an increase in the growth of seedlings associated with antagonistic strains. In addition, Liu et al. (2012) demonstrated by recombination of the crylE gene that $B$. thuringiensis was able to control pests and showed antifungal activity against 6 different phytopathogens. This demonstrates the potential of the Bacillus genus in the production of compounds with biotechnological potential and use as biological control agents for diverse cultures.

The percentages of inhibition obtained with the 3 Bacillus species that were identified in this study were within expectations because the inhibition efficacies obtained for both bacteria and yeast strains used for biological control vary based on the organism tested. Analysis of the antagonistic activity of $B$. subtilis against $F$. oxysporum ranged from 25 to $34 \%$, and the activity was 100\% against Botryodiplodia theobromae (Swain and Ray, 2009). When using rhizosphere and endorhiza fungi against Verticillium dahliae, inhibitions were shown to range from 8.58 to $69.78 \%$ (Zheng et al., 2011).

\section{ACKNOWLEDGMENTS}

Research supported by the Conselho Nacional de Desenvolvimento Científico e Tecnológico (CNPq), Fundação de Amparo à Pesquisa do Estado do Amazonas (FAPEAM), and Empresa Brasileira de Pesquisa Agropecuária (Embrapa).

\section{REFERENCES}

Araújo JM, Silva AC and Azevedo JL (2000). Isolation of endophytic actinomycetes from roots and leaves of maize (Zea mays L.). Braz. Arch. Biol. Technol. 43: 447-451.

Arguelles-Arias A, Ongena M, Halimi B, Lara Y, et al. (2009). Bacillus amyloliquefaciens GA1 as a source of potent antibiotics and other secondary metabolites for biocontrol of plant pathogens. Microb. Cell Fact. 8: 63.

Azevedo JL and Araujo WL (2007). Diversity and Applications of Endophytic Fungi Isolated from Tropical Plants. In: Fungi: Multifaceted Microbes (Ganguli BN and Deshmukh SK, eds.). CRC Press, Anamaya Publishers, Boca Raton, 189-207.

Azevedo JL, Maccheroni WJ, Pereira JO and Araújo WL (2000). Endophytic microorganisms: a review on insect control and recent advances on tropical plants. Electron. J. Biotechn. 3: 40-65.

Bell CR, Dickie GA, Harvey WLG and Chan JWYF (1995). Endophytic bacteria in grapevine. Can. J. Microbiol. 41: 46-53.

Ceballos I, Mosquera S, Angulo M, Mira JJ, et al. (2012). Cultivable bacteria populations associated with leaves of banana and plantain plants and their antagonistic activity against Mycosphaerella fijiensis. Microb. Ecol. 64: 641-653.

Coombs JT, Michelsen PP and Franco CMM (2004). Evaluation of endophytic actinobacteria as antagonists of Gaeumannomyces graminis var. tritici in wheat. Biol. Control 29: 359-366.

Hallmann J, Quadt-Hallmann A, Mahaffee WF and Kloepper JW (1997). Bacterial endophytes in agricultural crops. Can. J. Microbiol. 43: 895-914.

Kildea S, Ransbotyn V, Khan MR and Fagan B (2008). Bacillus megaterium shows potential for the biocontrol of Septoria tritici blotch of wheat. Biol. Control 47: 37-45.

Konecka E, Baranek J, Hrycak A and Kaznowski A (2012). Insecticidal activity of Bacillus thuringiensis strains isolated from soil and water. Scientific World J. 2012: 710501.

Lian J, Wang Z and Zhou S (2008). Response of endophytic bacterial communities in banana tissue culture plantlets to Fusarium wilt pathogen infection. J. Gen. Appl. Microbiol. 54: 83-92.

Lira-Cadete L, Farias ARB, Souza AP and Costa DP (2012). Variabilidade genética de bactérias diazotróficas associadas a plantas de cana-de-açúcar capazes de solubilizar fosfato inorgânico. Biosci. J. 28: 122-129. 
Liu Q, Roh JY, Wang Y, Choi JY, et al. (2012). Construction and characterisation of an antifungal recombinant Bacillus thuringiensis with an expanded host spectrum. J. Microbiol. 50: 874-877.

Ma Y, Prasad MN, Rajkumar M and Freitas H (2011). Plant growth promoting rhizobacteria and endophytes accelerate phytoremediation of metalliferous soils. Biotechnol. Adv. 29: 248-258.

Mendes R and Azevedo JL (2007). Valor Biotecnológico de Fungos Endofíticos Isolados de Plantas de Interesse Econômico. In: Micologia: Avanços no Conhecimento. (Maia LC, Malosso E and Yano-Melo AM, eds.). Ed. Universitária da UFPE, Recife, 129-140.

Mojica-Marín V, Luna-Olvera HA, Sandoval-Coronado CF and Pereyra-Alférez B (2008). Antagonistic activity of selected strains of Bacillus thuringiensis against Rhizoctonia solani of chili pepper. Afr. J. Biotechnol. 7: 1271-1276.

Montañez A, Blanco AR, Barlocco C and Beracochea M (2012). Characterization of cultivable putative endophytic plant growth promoting bacteria associated with maize cultivars (Zea mays L.) and their inoculation effects in vitro. Appl. Soil Ecol. 58: 21-28.

Pérez-García A, Romero D and de Vicente A (2011). Plant protection and growth stimulation by microorganisms: biotechnological applications of Bacilli in agriculture. Curr. Opin. Biotechnol. 22: 187-193.

Pillay VK and Nowak J (1997). Inoculum density, temperature, and genotype effects on in vitro growth promotion and epiphytic and endophytic colonization of tomato (Lycopersicon esculentum L.) seedlings inoculated with a Pseudomonas bacterium. Can. J. Microbiol. 43: 354-361.

Pimentel MR, Molina G, Dionisio AP, Marostica Junior MR, et al. (2011). The use of endophytes to obtain bioactive compounds and their application in biotransformation process. Biotechnol. Res. Int. 2011: 576286.

Quadt-Hallmann A, Hallmann J and Kloepper JW (1997). Bacterial endophytes in cotton: location and interaction with other plant-associated bacteria. Can. J. Microbiol. 43: 254-259.

Rebib H, Hedi A, Rousset M and Boudabous A (2012). Biological control of Fusarium foot rot of wheat using fengycinproducing Bacillus subtilis isolated from salty soil. Afr. J. Biotechnol. 11: 8464-8475.

Reiter B, Burgmann H, Burg K and Sessitsch A (2003). Endophytic nifH gene diversity in African sweet potato. Can. J. Microbiol. 49: 549-555.

Stolzfus JR, So R, Malarvithi PP and Ladha JK (1997). Isolation of endophytic bacteria from rice and assessment of their potential for supplying rice with biologically fixed nitrogen. Plant Soil 194: 25-36.

Strobel G, Daisy B, Castillo U and Harper J (2004). Natural products from endophytic microorganisms. J. Nat. Prod. 67: 257-268.

Sun L, Qiu F, Zhang X, Dai X, et al. (2008). Endophytic bacterial diversity in rice (Oryza sativa L.) roots estimated by $16 \mathrm{~S}$ rDNA sequence analysis. Microb. Ecol. 55: 415-424.

Swain MR and Ray RC (2009). Biocontrol and other beneficial activities of Bacillus subtilis isolated from cowdung microflora. Microbiol. Res. 164: 121-130.

Tamura K and Nei M (1993). Estimation of the number of nucleotide substitutions in the control region of mitochondrial DNA in humans and chimpanzees. Mol. Biol. Evol. 10: 512-526.

Tamura K, Peterson D, Peterson N, Stecher G, et al. (2011). MEGA5: molecular evolutionary genetics analysis using maximum likelihood, evolutionary distance, and maximum parsimony methods. Mol. Biol. Evol. 28: 2731-2739.

Thomas P, Swarna GK, Roy PK and Patil P (2008). Identification of culturable and originally non-culturable endophytic bacteria isolated from shoot tip cultures of banana cv. Grand Naine. Plant Cell Tiss. Org. 93: 55-63.

Torres NI, Noll KS, Xu S, Li J, et al. (2013). Safety, formulation, and in vitro antiviral activity of the antimicrobial peptide subtilosin against herpes simplex virus type 1. Probiotics. Antimicrob. Proteins 5: 26-35.

Wang B, Yuan J, Zhang J and Shen Z (2012). Effects of novel bioorganic fertilizer produced by Bacillus amyloliquefaciens W19 on antagonism of Fusarium wilt of banana. Biol. Fertil. Soils 49: 435-446.

Weber OB, Muniz CR, Vitor AO and Freire FCO (2007). Interaction of endophytic diazotrophic bacteria and Fusarium oxysporum f. sp. cubense on plantlets of banana "Maça". Plant Soil 298: 47-56.

Wulff EG, Mguni CM, Mortensen CN and Keswani CL (2002). Biological control of black rot (Xanthomonas campestris pv. campestris) of brassicas with an antagonistic strain of Bacillus subtilis in Zimbabwe. Eur. J. Plant Pathol. 108: 317-325.

Xie F, Zhu T, Zhang F, Zhou K, et al. (2013). Using Bacillus amyloliquefaciens for remediation of aquaculture water. Springerplus. 2: 119.

Yuan J, Raza W, Shen Q and Huang Q (2012). Antifungal activity of Bacillus amyloliquefaciens NJN-6 volatile compounds against Fusarium oxysporum f. sp. cubense. Appl. Environ. Microbiol. 78: 5942-5944.

Yuan J, Ruan Y, Wang B, Zhang J, et al. (2013). Plant growth-promoting rhizobacteria strain Bacillus amyloliquefaciens NJN-6-enriched bio-organic fertilizer suppressed Fusarium wilt and promoted the growth of banana plants. J. Agric. Food Chem. 61: 3774-3780.

Zeriouh H, Romero D, Garcia-Gutierrez L, Cazorla FM, et al. (2011). The iturin-like lipopeptides are essential components 
in the biological control arsenal of Bacillus subtilis against bacterial diseases of cucurbits. Mol. Plant Microbe Interact. 24: 1540-1552.

Zheng Y, Xue QY, Xu LL and Xu Q (2011). A screening strategy of fungal biocontrol agents towards Verticillium wilt of cotton. Biol. Control 56: 209-216.

Zinniel DK, Lambrecht P, Harris NB, Feng Z, et al. (2002). Isolation and characterization of endophytic colonizing bacteria from agronomic crops and prairie plants. Appl. Environ. Microbiol. 68: 2198-2208. 